СоцИОЛИНГВИСТИКА

DOI: $10.22363 / 2312-9182-2019-23-1-9-22$

\title{
Cultural bias and Sociolinguistics
}

\author{
Dick Smakman \\ Leiden University, Centre for Linguistics \\ PO Box 9515, 2300 RA, Leiden, Netherlands
}

\begin{abstract}
Peoples and individuals around the globe continuously develop their own communicative habits. With each generation, adjustments to changing circumstances are made - economic circumstances, natural circumstances, and, for instance, mobility circumstances. The outcome of such transitions is cultural variation, which is visible in hierarchical social systems, belief systems, legal systems, traditions, attire, and all kinds of rituals. Communicative systems are part of culture, and they deserve a role in research focussing on language and communication. However, applying culture as a variable is a challenge, not only because of the cultural variation between peoples and individuals but also because the effects of culture on actual language utterances are hard to measure. Another issue is the dominance of Anglowestern cultural patterns in many analyses. This paper explains these issues and critically reviews the various criteria that well-known cultural models — like the one by Hofstede (1980), Lewis (1969), and Hall $(1959,1976)$ - use to categorise cultures. Examples of such criteria are: region, relationship with uncertainty, femininity/masculinity, and power relations. The paper concludes by giving a number of practical solutions to the challenge of treating culture as a variable in sociolinguistic research. These solutions are related to, amongst others, the reviewing process for journals, widespread norms of 'good academic language', author/editor selection, cross-cultural academic cooperation, and sharing of funds.
\end{abstract}

Keywords: cultural models, sociolinguistics, Anglowestern bias, cultural criteria, solutions

\section{Культурные предубеждения и социолингвистика}

\author{
Дик Смакман \\ Лейденский университет, Центр лингвистики \\ PO Bох 9515, 2300 RA, Лейден, Нидерланды
}

Люди во всем мире постоянно развивают свои собственные коммуникативные обычаи. Каждое поколение приспосабливает их к меняющимся обстоятельствам - экономическим, природным, демографическим и т.д. В результате возникает культурное разнообразие, проявляющееся в социальной иерархии, верованиях, законотворчестве, традициях, одежде и разного рода ритуалах. Коммуникативные системы являются частью культуры и заслуживают внимания как объект лингвистических и коммуникативных исследований. Однако здесь возникают некоторые 
сложности не только из-за культурной вариативности, но и из-за того, что влияние культуры на язык трудно измерить. Проблема также состоит в том, что во многих исследованиях превалирует западная англоязычная модель анализа. В данной статье дается критический обзор этих проблем, а также критериев, используемых в известных моделях анализа культуры Хофстеде (Hofstede 1980), Льюиса (Lewis 1969), Холла (Hall 1959, 1976), таких как отношение к неопределенности, фемининность/маскулинность, дистанция власти и др. В статье предлагается ряд практических решений, способствующих эффективному рассмотрению культуры как переменной в социолингвистических исследованиях. Они, в частности, касаются процесса рецензирования для научных журналов, широко распространенных норм «хорошего научного языка», выбора авторов и редакторов, межкультурного научного сотрудничества и совместного использования научных фондов.

Ключевые слова: модели исследования культуры, сочиолингвистика, англо-западныле предубеждения, культурные критерии, решения

\section{INTRODUCTION}

Every society has historically developed under unique circumstances. Different natural and climatic conditions have led to different communities of people, each with their own systems of beliefs, ideologies, and morals, and each with their own system of wealth and power division. The different roles of women and men, in particular, have been influenced by these natural conditions; societies that were originally of the huntergatherer type nowadays tend to have different roles assigned to the sexes, compared to societies that were originally horticultural or, for instance, pastoral (Evans-Pritchard 1951; Halliday 2001). The natural outcome of this variation are communicative habits that reflect the cultures in question. These are deeply engrained in societies and are passed on from generation to generation, and every generation adapts the passedon system to their emerging practical and symbolical needs. The communication patterns of each member in each new generation are thus affected by the practices and beliefs instilled through their culture, by changing needs in this society, but also through contact with other societies as well as regional and global tendencies and technical progress.

This paper seeks to treat culture as one of the key determinants of sociolinguistic systems (i.e. systems of interpersonal communication within societies); culture partly determines how people within societies communicate. It investigates how to treat culture as a sociolinguistic variable. The basic premise this paper departs from is that there is a certain overrepresentation of Anglowestern ideologies in the literature, and an underrepresentation of cultures that are not Anglowestern, including cultures that large groups of speakers adhere to. This is a fact, and this is a problem (Coulmas 2013; Meyerhoff \& Nagy 2008; Smakman 2015) because this cultural bias has led to cultural assumptions. It has also led to assumptions as to whether and how to incorporate culture methodologically in research. A field like Sociolinguistics, in which human behavioural tendencies are an important factor, is particularly sensitive to this.

First, the nature of the problem is described. Then, an outline is given of the criteria that are often used to define culture. Some suggestions are then presented that may lead to an improvement of the situation; i.e. a 'globalising' Sociolinguistics that represents a broad range of cultures rather than a predominantly Western cultural concept. 


\section{THE NATURE OF THE PROBLEM}

Coulmas (2013) rightly indicated that Variationist Sociolinguistics is predominantly a Western science. The same thing can be said about post-Variationist waves. Meyerhoff and Nagy (2008) laid out the realities of the mechanisms behind this bias by illustrating that linguistic situations in the United States received relatively much attention in two major international journals in the field of Sociolinguistics, namely the Journal of Sociolinguistics and Language Variation and Change. They considered this a good motivation to report more on non-western language situations and make them publically available. The issue the above authors pointed out is one of availability and accessibility of research, but another, perhaps equally serious issue is the bias in the interpretation of data. Introductory books on Sociolinguistics often place the Anglowestern way of thinking and forming categories at the basis of argumentation. Meyerhoff and Nagy (2008) as well as an important author like Jennifer Jenkins (2009) pointed out what everyone knows to be true, namely that most introductions into the field of Sociolinguistics themselves stem from an Anglophone cultural pattern and will interpret language situations through that perspective. Situations that are different from what the Western authors are used to are tacitly presented as deviant.

The treatment of standard language in the literature provides a good example to demonstrate the issue (Smakman \& Barasa 2016). The most common point of departure in the literature dealing with the language norm is a monolingual culture (usually a nation state) with an obvious standard language (e.g., Swedish in Sweden and Spanish in Spain). This language is spoken in the media and in official and educational contexts. It is associated with the nation state's history and identity and is broadly supported by the nation's inhabitants, who consider it a neutral lingua franca (Smakman 2012). Educated speakers tend to speak this language. Indeed, in European countries like the United Kingdom, Denmark, France, and the Netherlands this situation is a reality. Language norms and the norm language in Africa and some Asian countries ill-fit the traditional standardness paradigm, and these themes - probably as a result of the bad fit — do not receive the sociolinguistic attention they deserve. It ill-fits because in some countries an old colonial language exists as a language norm besides a more autochthonous language. Heavy codeswitching - usually by speakers who are highly multilingual - is often the language norm in daily communication, and this also does not fit the traditional model. There is often also a nativised standard language, which is an adapted western language (most notably English and French) that accommodates local meanings and habits and generally the cultural and linguistic needs of the local community (Kachru 1976). So, all in all, there are several parallel language norms in some non-Western countries, each of which fulfills a different function. While this situation is usually described as deviant, it is highly common and deserves its own place in norm-language theories. However, the only language-norm paradigm that has so far had any theoretical impact is the Western one, which gives other situations an aura of deviancy, and this obstructs efforts towards a broader and revised mainstream theory.

Other examples of underlying assumptions that negatively affect the attention paid to non-Western situations can be found in Smakman and Heinrich (2015). This volume demonstrates how Western theoretical models are dominant to such a degree that they reduce non-Western communicative settings to near-oddities, while logically speaking, 
these setting should be part of a larger theoretical framework. The volume provides a string of examples from countries where Western paradigms do not fit. The importance of dance as a form of intergenerational communication in communities in Alaska is explained, as are the intricate workings of prestige in Saami communities in the far north of Europe. Knowledge of older traditions, values, and language forms are a source of prestige in both the Saami and Alaskan native communities, and thus it is hard to differentiate the knowledge about linguistic and non-linguistic things. Prestige of someone's language lies not only in the actual language use but in the knowledge, actions, and experiences of the speaker. Politeness and gender roles in Tokyo are also described in this volume to demonstrate how assumptions hereon in mainstream discourse are in fact incorrect. The global agreement amongst such urban and less urban communities is not part of any mainstream theory. The volume reveals that many of the situations that do not fit into mainstream paradigms at some level actually apply to very large groups of speakers.

Smakman (2015) tried to clarify the mechanisms behind the Western dominance in sociolinguistic theory-making by investigating academic output in the field. He took into consideration issues such as the likely cultural backgrounds of members of editorial boards and authors. He correlated these with population size, command of English, and economic development of the country where the university of the editors and authors was. Smakman's data were drawn over several decades and showed no tendency of improvement in the last three or four decades. His data showed that the dominance of Western researchers, and Anglowestern ones in particular, is obvious and easily visible: famous sociolinguists tend to be native speakers of English, journals are mainly run by academics working at Anglophone universities - most of whom will be native speakers of English and all of whom will be acting in line with the local cultural norms of academia - , and by far most internationally renowned introductory books are by Anglophone authors. Being a good speaker of English as a second language seems to correlate with the possibilities of getting research published as well. The correlation between publishing success and human development (place on the Human Development Index) of the country where an author's university is based is even more striking, with by far most articles coming from affluent countries with western-based democratic systems.

Relatively less attention is paid to non-Anglowestern societies in the articles studied, but the contribution of data about these regions is nevertheless considerable (Smakman 2015). The good news is that although the areas with most language variation are understudied, the general attention paid to non-Western languages and cultures is nevertheless positive. However, because non-Anglophone languages and cultures are studied by a relatively high percentage of authors inspired by the Anglowestern models and modes of research, ideologies from this cultural realm will inevitably underlie the analyses and serve as a set of contrastive premises. This will be visible in the choice of research questions, variants of variables, and socio-psychological explanations of research findings. Offering respondents categories such as 'man'/'woman' and 'feminine'/'masculine' is problematic in countries where other genders are an established part of society. Western perceptions of age, too, are problematic. In Thai, age poses a challenge if one wants to investigate its effects, because many personal pronouns in that 
language depend on relative rather than absolute age of interlocutors (Intachakra 2001), in addition to social and contextual factors, which necessitates determining age relative to others rather than just the speaker's biological age. Cheshire (2005) explained how some communities attach more importance to rituals than actual age and how age-related categorisation of Xhosa men (southern Africa) is on the basis of initiation rituals. Therefore, applying Western perceptions of age and gender identity when researching these situations is obviously problematic.

\section{CRITERIA TOWARDS CULTURAL CATEGORISATION}

Mainstream Sociolinguistics is mainly modelled on one specific type of sociolinguistic system, namely that which can be called 'solidly modern societies'. Solidly modern societies in the Western world represent the material from which mainstream sociolinguistic theory was built. They, however, do not represent a 'natural' or 'normal' or 'unproblematic' type, but are also an expression of specific cultural settings. There exist many ways to be solidly modern. Different combinations of a bundle of features define modernity differently for various regions around the world (Eisenstadt 1973), which is why non-Western modernized settings may be very different from those depicted in mainstream Sociolinguistics (Greenberg 2015).

Different types of societies must give rise to different types of sociolinguistic study. What gives structure to society needs to be taken into account first before specific sociolinguistic theories are applicable. The culture of societies thus needs to be defined. Many different models exist to define culture (some well-known ones are mentioned below), and they share certain criteria. Below are ten often used criteria to determine or describe culture that such models have yielded.

\subsection{Region}

Regions are not always helpful in explaining why sociolinguistic systems differ. Regions have often been defined in an ad-hoc manner, usually for political rather than cultural reasons. It would be far-fetched to expect, for instance, that concepts such as 'Southeast Asia' or 'the Slavic area' could be employed to determine patterns of language use. The borders around regions cannot be drawn with any degree of objectivity. Region is nevertheless one of the most convenient and common ways of categorising culture, as it is generally agreed that in very broad terms, ethnicity, religion, and other obvious features correlate with region. Regional categorisations often reflect one of the region's dominant ideologies, while ignoring other important ideologies that are equally native. Sociolinguistic differences cannot easily be generalised across regions.

\subsection{Relationship with uncertainty}

The Uncertainty Avoidance dimension, as proposed by Hofstede (1980), refers to the way a society deals with uncertainties that the future may bring. Some societies are more controlling than others; they tend towards creating safety and security, while others take a more laissez-faire approach. This criterion will in particular be able to provide insight into power and gender relations, including the language choices of individuals and groups that stem from these. 


\subsection{Invidividualism vs collectivism}

A distinction is often made between societies that focus more on the individual and their needs, and those in which groups are the main focus in communication. Typically, members of individualist societies focus on the interests of their families, friends, and themselves. In collectivist societies, on the other hand, loyalty within groups, e.g. professional ones, outside the family is more common. The group that one belongs to takes preference in deciding on obligations and responsibilities and loyalties, rather than one's own or one's family's interests. Western societies are considered to be more individualistic in this sense, while Asian societies are stereotypically group-oriented. Morales, López-Sáez, and Vega (1998) critically addressed this cultural distinction, while Hofstede (1980) assumed this distinction to be a feasible criterion to distinguish between cultures. The workings of this criterion will present themselves in spoken, day-to-day discourse, with some speakers addressing the interlocutor's face as well as a group's face more than their own, while speakers from another culture give relatively much attention to their own face.

\subsection{Economic/human development}

Halliday (2001) has convincingly argued that a different economic organisation of society must be expected to manifest syntactically, insisting that "major upheavals in human history are also linguistic upheavals" (180). He suggested a distinction between hunter-gatherer societies, settlement-pastoral communities, classic iron-age cultures, and cultures marked by the advancement of learning and modernity. Size, structure, density, composition, etc. of hunter-gatherer societies, agricultural societies, industrial societies, and post-industrial knowledge societies differ considerably, and, in accordance with these differences, society is regulated and maintained differently as well. Besides linguistic effects, this also has sociolinguistic effects. What is missing in Sociolinguistics so far is how cultures create different types of sociolinguistic systems as a result of different economic organisation of societies. The relatively recent economic changes in national economies (due to globalisation, digitisation, and technical advancement) will affect communication in various economies differently, and this needs more attention.

Human development largely depends on economic structure but takes a broader approach, the idea being that wealth alone does not determine perceptions of happiness and well-being. The Human Development Index, as developed by the United Nations Development Programme (http:/hdr.undp.org/en/content/human-development-index-hdi), can be used to this end. People's worldviews change when they as individuals and the society around them undergo socio-economic development (Inglehart \& Welzel 2004, 2005). The HDI combines three factors: length and happiness of one's life, educational level, and standard of living. The latter largely reflects economic development. Countries can be placed on a cline with categories: 'developing countries', 'less developed countries', 'developed countries', and 'unstable multilingual communities'. This aspect as a source of communication style has received relatively little attention. 


\subsection{Power relations}

Individuals and groups in societies are generally not equal, and societies have ways to express the way culture handles this difference (Hofstede 1980). Power distance reflects the acceptance of this difference within a society by its powerful and less powerful members and by all kinds of institutions and organisations. This does not only affect the language (like politeness forms) but it also directly affects the way speakers address each other (structure of use of politeness forms), and even whether they actually do.

\subsection{High/low context}

To categorise cultures across the globe, the British polyglot Richard Lewis (1996) departed from the existing cultural model of High-context cultures and Low-context cultures (Hall 1959, 1976), which roughly refers to the overtness of information in communication. Lewis' model charts countries triangularly in terms of the tendency towards Reactive, Linear-active, or Multi-active communication. Linear-active communication is associated with an equal contribution of interlocutors to conversations, planned communication patterns, polite directness, goal-orientedness, factuality, restrained body language, and attaching a strong role to the written word. Multi-active communication, on the other hand, involves relatively much talking, broad topic planning, confrontation, emotion, people-orientedness, placing feelings before facts, relationship-orientedness, importance of the spoken word, and unrestrained body language. Reactive patterns involve much listening, reacting to actions of the interlocutor, mainly looking at general principles, polite and unconfrontational indirectness, people/harmony-orientedness, the assumption that statements are promises, and subtle body language. Besides addressing linguistic differences based on this phenomenon, Lewis hypothesised in detail about how culture affects communication practices within communities through the overtness of information.

\subsection{Femininity/masculinity}

Cultures can be stereotypically masculine or feminine (Hofstede 1980; Hofstede Hofstede \& Minkov 2010). Highly masculine societies are driven by competition, achievement, and success. High femininity refers to concerns about the lives of others and about the quality of life in general. Standing out in a crowd is not admirable in feminine societies. Although the stereotypical assumptions underlying this binary qualification may be perceived as Western and sexist in themselves, this division is often felt to exist and determine language choices across the globe.

\subsection{Conservative versus progressive cultures}

Some societies more than others maintain links with their own past. While conservative, traditional cultures are hesitant towards change and prefer to rely on existing truths and societal patterning, more progressive societies assume that the truth depends on the situation. Although generalisations should not be made, and cities in particular may often deviate from certain patterns, it could be suggested that North- 
West Europe is at the more progressive end of the scale, while, for instance, certain Eastern European and African countries may tend more towards more conservative/ traditional patterns of thought. Communicative patterns, especially lexical choices, may reveal this aspect of culture. Progressive manners of communication may involve lexical choices that reveal less sensitivity to social hierarchy.

\subsection{Tendency towards indulgence}

Another criterion to define culture is a society's tendency to give in to indulgence (Hofstede, 1980). The idea is that some societies allow their members to indulge themselves more (basically, enjoy themselves) while other societies aim more at the control and restraint of such natural urges. It should be clear that this aspect of culture will affect language use, in particular intonation and lexical patterns.

\subsection{Cultural values}

Approaching culture through values entails capturing how people in various cultures value fundamental aspects in life such as religion, happiness, materialism, gender roles, freedom of choice, self-expression, tradition, and authority. The well-known World Values Survey (WVS 2015) has tried to do this. Halman et al. (2008) and Inglehart \& Welzel (2004) subdivided cultures in the world into nine categories: (1) Confucian, (2) South Asia, (3) African-Islamic, (4) Latin America, (5) English-speaking, (6) Catholic Europe, (7) Protestant Europe, (8) Orthodox, and (9) Baltic. Countries were grouped schematically with other countries within one of these cultural patterns, and at the same time they were plotted on the basis of two value scales, namely 'Survival-Self-Expression' and 'Traditional-Secular-Rational'. Traditional Values emphasize religion, ties between parent and child, respecting authority, and family values. Divorce, abortion, euthanasia, and suicide tend to be rejected in these societies. Nationalism is strong. The opposite of Traditional Values are Secular-Rational Values, which place less emphasis on traditional aspects such as religion and the family, and which are more liberal to euthanasia, divorce, and abortion. Survival Values place emphasis on physical and economic security, and are associated with ethnocentrism and low levels of tolerance and trust. The opposite of Survival Values, namely SelfExpression Values, emphasise liberal values like protection of the environment, tolerance towards foreigners and non-heterosexual people, and gender equality. A relatively high demand of individuals to participate in the decision-making of authorities is also part of this value. Where one's culture is situated on these scales, affects relationships and, as a result, communication patterns.

Several other authors have discussed human values that determine (perceptions of) culture. An important one is Schwartz (2012), who approached values in a less regional manner and presented a theory involving basic human values, including the nature of values, the features common to values, and what distinguishes one value from another. Schwartz distinguished ten basic personal values that are recognized across cultures. Schwartz' idea was that values form a circular structure that reflects the motivations each value expresses. This circular structure captures the conflicts and compatibility among the ten values and is presented as potentially culturally universal. 


\subsection{Other investigations}

Other researchers have also made efforts to define and align criteria to determine cultures or, simply, describe cultures. Smith, Fischer, Vignoles, and Bond (2013) took a social semiotic approach, Wodak (2001) developed a gender-centred approach, and Fairclough (2003) revealed culture through critical discourse analysis. The body of research on culture, including considerable empirical evidence through large-scale surveys, as well as research on individuals shows the interest in fathoming the topic of culture, and this interest seems to be increasing in a globalised world. In such a world, cultural categories become more fluid, and this fluidity leads to more categories and more awareness that culture and individual are not connected in straightforward ways and that playing with culture by individuals is increasingly common.

\section{THE CHALLENGES OF APPLYING CULTURE CRITERIA}

Hofstede (n.d.) stated that "[w]e can $<\ldots>$ use such country scores based on the law of the big numbers." However, he starts by saying that "[i]t may well be that the differences among individuals in one country culture are bigger than the differences among all country cultures". Indeed, there is tension between the idea of generalisability on the one hand, and individual/situational variation and communicational fluidity on the other. To make things even more complex, today most cultures are transforming under the influence of globalisation and self-reflection, giving way to what sociologists call 'liquid modernity' (Bauman 2000), as well as 'late modernity' or 'reflexive modernity' (Giddens 1991).

Applying the above criteria (and others) in actual research is also problematic. There is no agreement on the nature and degree of impact of the criteria, and interculturally recognised cultural descriptions do not exist yet. To put it simplistically: all the criteria make sense, they all apply in some shape or form, but they tend to generalise, and they are often too subjective to be used in empirical research. Morales et al. (1998), for example, found that qualifying individuals as either 'individualistic' or 'collectivist' could not be used to predict politeness strategies they employ under various circumstances. Those individuals have their own relationship with their cultures, and what is more, each individual is part of a collective, making a distinction between 'individualistic' and 'collectivist' societies a rather forced one. Lozerand (2015) expanded this argument and deconstructed ideas about 'collectivist' non-Western societies as an 'Orientalist' discourse of the $19^{\text {th }}$ century, in which Western scholars departed from what they perceived to be physical resemblance of non-Western individuals, projecting on these 'similar looking people' a high degree of 'psychological resemblance' as well. This then led them to conclude that the non-Western societies lacked 'individual originality' and were thus, in a word, 'collectivist'. This idea was then uncritically reproduced in Western Oriental Studies, from which it found entry into other disciplines.

Criteria are also used in culturally biased ways. Models that define cultural patterns tend to ignore the emic/etic differentiation. Indeed, concepts like 'religion', 'authority', 'divorce', 'age' or 'gender' mean something very different across societies in the world. 
The underlying conceptualisation is thus again a Western one, i.e. Western ideas about religion, authority, divorce, age, gender, or other factors underlie the research (Inglehart \& Welzel 2004; Lewis 1996; WVS 2015).

These criteria tend to confuse culture with country and nation state (Greenberg 2015; Pennycook 2018). Given the fact that Sociolinguistics is ultimately about diversity, the use of models sweeping the existing multilingual and multicultural make-up of all societies around the world under the carpet is questionable. The views are static, placing given cultures in some place in the proposed grid. These cultures have, however, all arrived there at some point of time; they have a trajectory, and they are moving on to other places, too. The idea that society, culture, and language are dynamic should be part of any model.

A final issue worth noting is that Westernisation and industrialisation have had their impacts on traditional societies, and many societies have found their own ways of incorporating these inevitable tendencies, making them part of their contemporary culture. Different cultures do this in very different ways. These two tendencies, which inevitably involve a degree of hybridisation, may to a degree hide the original culture, while communicative and other patterns arising from the original culture may be as alive as ever.

\section{SOLUTIONS}

The above issues do not merely apply to Linguistics or Sociolinguistics but to a broad range of disciplines. The focus here is on Sociolinguistics. Smakman (2015) and Smakman, Barasa, and Smith-Christmas (submitted) presented a number of practical solutions to the problem at hand. They suggested reconsidering the reviewing process for journals and critically addressing widespread norms of 'good academic language'; see also Smakman and Duda-Osiewacz (2014). They also suggested that translation can be used as a tool; authors write in their native tongue, and a translator and the author together translate the text into English. Furthermore, authors can be found in different ways from what is currently the case; for instance, by reaching out to specific authors, rather than waiting for articles to be submitted. They furthermore addressed the issue of funding and of intercultural academic cooperation. Finally, they suggested that the selection of editors deserves attention, as well as the availability of articles and their dissemination. Such initiatives could contribute to cultural emancipation in sociolinguistic theorisation and growth of non-Western research.

More publications on lesser known sociolinguistic settings obviously help globalise Sociolinguistics to a degree (Meyerhoff \& Nagy 2008) and in the process help make lesser known cultures part of mainstream theory. One such effort is the volume by Stanford and Preston (2009), which focuses on under-represented minority communities; on descriptions of specific aspects of lesser-known sociolinguistic systems. Furthermore, the individual chapters in Bolton and Kwok (1992) described a linguistic phenomenon in a specific country or community. The Routledge Handbook of Sociolinguistics around the World (Ball 2010) dealt with larger areas and can thus be considered a good source of background information on sociolinguistic systems across the globe because it focuses on "notable features" (xviii) of regional and smaller-scale cultural settings. Smakman and Heinrich $(2015,2018)$ also placed lesser known sociolinguistic situations on the map. 
An effort towards good practice that the author of this article has undertaken is Smakman and Barasa (2016). In this article, the different cultures of the authors (Dutch and Kenyan) led to a publication that has both Anglowestern and non-Anglowestern influences. They described the phenomenon of the 'norm language', which is often formalised and expressed through 'standard', 'national' or 'official' languages. The approach was one of not taking the western standard language concept as a point of departure but looking at the phenomenon that it is the upshot of, namely the apparent need of peoples to form and maintain some sort of linguistic norm. Smakman and Barasa (2016) explained the relevant factors when defining the language; colonialism, multilingualism of individuals, the existence of parallel language norms (including a nativised standard), and the possible absence of an "exclusive" interpretation of the standard language; see also Smakman (2012). The solutions they offered were to separate the functions of the standard language, to distinguish between the spoken and written norm, to treat the "codeswitched" variety as a possible standard, and to detach the norm language from its automatically assumed reliance on prestige and power. That way, culture is viewed from multiple angles, which leads to a certain nuance and fewer generalisations.

The way forward seems to be to consider new methodologies, and in particular be inspired by Linguistic Anthropology and Ethnography. These two disciplines have an edge over Sociolinguistics when it comes to culture-sensitive approaches, as they have a longer history of critically dealing with culture as a factor. This is due to the simple fact that these fields develop insights from within societies and communities rather than insights that are strongly influenced by the researchers' backgrounds. Methodologically, research interpretation is viewed critically, and participant interpretation plays an important role. This requires long and intensive periods of fieldwork, observation and participation. It also requires awareness of one's own cultural biases when interpreting data; our 'conceptual lock' (Gould 2000); "reality does not speak to us objectively, and no science can be free from constraints of psyche and society" (276); one needs to analyse one's own cultural experiences when analysing those of others.

Sociolinguistics compensates for the relative lack of scrutiny of individuals and smaller groups with elaborate and detailed theories and methodologies, including controlled circumstances in lab-like settings. A solution then is to involve sociolinguists more in ethnographic and anthropological research, and in longer-term research. The outcome would be an approach that does not depart from existing descriptions of situations as an explanatory tool or from pre-determined variable-based research questions. Instead, the approach delves into the lowest, local, and most idiosyncratic cultural level, as well as the interpretation thereof by participants. It subsequently compares observations with research from other field studies and with existing cultural models.

(C) Dick Smakman, 2019

\section{REFERENCES}

Ball, M. J. (Ed.) (2010). The Routledge Handbook of Sociolinguistics around the World. London: Routledge.

Bauman, Z. (2000). Liquid Modernity. Cambridge: Polity Press. 
Bolton, K., \& Kwok, H. (Eds.). (1992). Sociolinguistics Today; International Perspectives. London, New York Routledge.

Coulmas, F. (2013). Sociolinguistics. The Study of Speakers' Choices. Cambridge: Cambridge University Press.

Eisenstadt, S. N. (1973). Tradition, Change and Modernity. New York: Wiley.

Evans-Pritchard, E. E. (1951). Social Anthropology. London: Cohen \& West Ltd.

Fairclough, N. (2003). Political Correctness: The Politics of Culture and Language. Discourse and Society, 14(1), 17-28.

Giddens, A. (1991). Modernity and self-identity. Self and society in the late modern age. Cambridge: Polity Press.

Gould, S. J. (2000). Wonderful Life. The Burgess Shale and the Nature of History. New York: Vintage.

Greenberg, M. L. (2015). The Slavic area. Trajectories, borders, centres and peripheries in the Second World. In D. Smakman \& P. Heinrich (Eds.), Globalising Sociolinguistics. Challenging and Expanding Theory (pp. 164-177). London: Routledge.

Hall, E. T. (1959). The Silent language. New York: Doubleday.

Hall, E. T. (1976). Beyond Culture. New York: Doubleday.

Halliday, M. A. K. (2001). New ways of meaning. The challenge to applied linguistics. In A. Fill \& P. Mühlhäusler (Eds.), The Ecolinguistic Reader (pp. 175-202). London: Continuum.

Halman, L., Inglehart, R. F., Díez-Medrano, J., Luijkx, R., Moreno, A., \& Basáñez, M. (2008). Changing Values and Beliefs in 85 Countries. Trends from the Values Surveys from 1981 to 2004. Leiden: Brill.

Hofstede, G. (1980). Culture's Consequences: International Differences in Work-Related Values. Beverly Hills CA: Sage Publications.

Hofstede, G. (n.d.). Hofstede insights. Retrieved from https://www.hofstede-insights.com.

Hofstede, G., Hofstede, G. J., \& Minkov, M. (2010). Cultures and Organizations: Software of the Mind (3 ed.). USA: McGraw-Hill.

Inglehart, R. F., \& Welzel, C. (2004). What insights can multi-country surveys provide about people and societies? APSA Comparative Politics Newsletter, 15(2), 14-18.

Inglehart, R. F., \& Welzel, C. (2005). Modernization, Cultural Change, and Democracy: The Human Development Sequence. Cambridge: Cambridge University Press.

Jenkins, J. (2009). World Englishes: a Resource Book for Students (2nd ed.). London: Routledge.

Kachru, B. B. (1976). Models of English for The Third World: White Man's Linguistic Burden or Language Pragmatics? TESOL Quarterly, 10(2), 221-239.

Lewis, R. D. (1996). When Cultures Collide. Leading across Cultures. London: Nicholas Brealey International.

Lozerand, E. (2015). Il n'y a pas d'individu au Japon. Critique et archeologie d'un stereotype. In C. Galan \& J.-P. Giraud (Eds.), Indiviu-s et démocratie au Japon (pp. 19-71). Toulouse: Presses Universitaires du Midi.

Meyerhoff, M., \& Nagy, N. (2008). Social lives in language. Sociolinguistics and multilingual speech communities celebrating the work of Gillian Sankoff. Amsterdam / Philadelphia: John Benjamins.

Morales, J. F., López-Sáez, M., \& Vega, L. (1998). Discrimination and beliefs on discrimination in individualists and collectivists. In S. Worchel, J. F. Morales, D. Páez, \& J.-C. Dechamps (Eds.), Social identity. International Perspectives (pp. 199-210). London / Thousand Oaks (California) / New Delhi: Sage Publications. 
Pennycook, A. (2018). Posthumanist Applied Linguistics. Abingdon/New York: Routledge.

Schwartz, S. H. (2012). An Overview of the Schwartz Theory of Basic Values. Online Readings. Psychology and Culture, 2(1).

Smakman, D. (2012). The definition of the standard language: a survey in seven countries. International Journal of the Sociology of Language, 218, 25-85.

Smakman, D. (2015). The westernising mechanisms in sociolinguistics. In D. Smakman \& P. Heinrich (Eds.), Globalising Sociolinguistics. Challenging and Expanding Theory. London: Routledge.

Smakman, D., \& Barasa, S. N. (2016). Defining 'Standard'. Towards a cross-cultural definition of the language norm. In I. Tieken-Boon van Ostade \& C. Percy (Eds.), Prescription and Tradition in Language. Establishing Standards across Time and Space (pp. 23-38). Bristol / Buffalo / Toronto: Multilingual Matters.

Smakman, D., Barasa, S. N., \& Smith-Christmas, C. (submitted). Towards cultural diversification in Sociolinguistics.

Smakman, D., \& Duda-Osiewacz, A. (2014). A contrastive rhetoric analysis of scholarly publications by Polish and Anglophone authors. Journal of Language Teaching and Learning, 4(2), $29-47$.

Smakman, D., \& Heinrich, P. (2015). Globalising Sociolinguistics. Challenging and Expanding Theory. London: Routledge.

Smakman, D., \& Heinrich, P. (Eds.). (2018). Urban Sociolinguistics. The City as a Linguistic Process and Experience. London: Routledge.

Smith, P. B., Fischer, R., Vignoles, V. L., \& Bond, M. H. (2013). Understanding social psychology across cultures. Engaging with others in a changing world. London: Sage.

Stanford, J., \& Preston, D. R. (2009). The Lure of a Distant Horizon. Variation in Indigenous Minority Languages. In J. Stanford \& D. Preston (Eds.), Variation in Indigenous Minority Languages (pp. 1-20). Amsterdam: John Benjamins.

Wodak, R. (2001). Gender and Language: Cultural Concerns. In N. J. Smelser \& P. B. Baltes (Eds.), International Encyclopedia of the Social \& Behavioral Sciences (pp. 5954-5960). Oxford: Pergamon.

WVS, W. V. S. (2015). Findings and Insights. Retrieved from http://www.worldvaluessurvey.org/ WVSContents.jsp.

\section{Article history:}

Received: 19 August 2018

Revised: 07 October 2018

Accepted: 30 October 2018

\section{История статьи:}

Дата поступления в редакцию: 19 августа 2018

Дата принятия к печати: 30 октября 2018

\section{For citation:}

Smakman, Dick (2019). Cultural bias and Sociolinguistics. Russian Journal of Linguistics, 23 (1), 9-22. doi: 10.22363/2312-9182-2019-23-1-9-22.

\section{Для цитирования:}

Smakman, Dick. Cultural bias and Sociolinguistics // Вестник Российского университета дружбы народов. Серия: Лингвистика $=$ Russian Journal of Linguistics. 2019. Т. 23. No 1. С. 9-22. doi: 10.22363/2312-9182-2019-23-1-9-22. 


\section{Bionote:}

DICK SMAKMAN, Ph.D., Lecturer at Leiden University Centre for Linguistics, Department of English. His research interests embrace sociolinguistics, phonetics, language learning and teaching, Dutch, English. He is a member of the editorial board of the International Journal of the Sociology of Language (IJSL). He publishes on the topics of sociolinguistics and the phonetics of English as a second language.

Contact information: e-mail: d.smakman@hum.leidenuniv.nl

\section{Сведения об авторе:}

ДИК СМАКМАН, Центр лингвистики Лейденского университета, г. Лейден, Нидерланды. Сфера научных интересов - социолингвистика, фонетика, изучение и преподавание языков, голландский и английский языки. Член редакционного совета научного журнала International Journal of the Sociology of Language (IJSL). Имеет публикации по проблемам социолингвистики и по преподаванию фонетики английского языка как иностранного.

Контактная информация: e-mail: d.smakman@hum.leidenuniv.nl 